\title{
Should We Clash or Should I Go? The Impact of Low Wage and Poor Working Conditions on the Exit-Voice Trade-Off
}

\section{Olivier Godechot ${ }^{1}-$ Zinaida Salibekyan $^{2}$}

Abstract. We use two linked employer-employee datasets to adapt Hirschman's model of consumer behaviour into the labour market and to argue that dissatisfaction with pay should favour exit while dissatisfaction with working conditions should favour voice. A deterioration of our working conditions index increases the probability of participation in collective action when an increase in log hourly wage decreases the probability of quitting. A rationale for this trade-off is based on information: first, information on the price of alternative options is more accessible than information on their quality; second, voice produces more information than exit and favours opportunities for specific improvements.

\section{Introduction}

Hirschman's seminal book Exit, Voice, and Loyalty (1970) is typically invoked in order to understand workers' strategies on coping with their wage and working conditions. Nevertheless, the mechanisms at the core of Hirschman's book are rarely analysed precisely and tested empirically. Hirschman does not deal with labour markets and concentrates mainly on consumers dissatisfied by the price and the quality of a product. In such situations, consumers must choose between two options, exit or voice. Economics traditionally stresses the importance of exit as the basic market mechanism: firms adapt to consumers' exit through price adjustment. On the contrary, Hirschman stresses the fact that the voice strategy may be more efficient than exit. This is the case when consumers are primarily dissatisfied with the quality of a product. The reason for this is informational: first voice conveys more information than exit and therefore helps firms to react to dissatisfaction through specific improvements, second the uncertainty regarding the quality of alternative options is higher than uncertainty regarding their price. ${ }^{1}$

The aim of this paper was to adapt Hirschman's model to labour markets. In the labour market, quitting, collective action, wages, and working conditions can be considered as direct equivalents of exit, voice, price, and quality of products on the market for goods and services, respectively. When do workers choose to take part in collective action? When do they quit? Transposing Hirschman's model onto the labour market predicts that

\footnotetext{
${ }^{1}$ Sciences Po, OSC-CNRS and MaxPo, 28 rue des Saint Pères, 75007 Paris, France. E-mail: Olivier.Godechot@sciencespo.fr

${ }^{2}$ Centre d'Etudes de l'Emploi et du Travail (CNAM-CEET), Immeuble Le Descartes 1, 29, promenade Michel Simon, 93166 Noisy le Grand Cedex, France.

E-mail: z.salibekyan@gmail.com
} 
dissatisfaction with pay should favour quitting while dissatisfaction with working conditions should favour collective action. The central mechanism relies on the information exchange at stake within those two strategies. Working conditions are a multi-dimensional and partly subjective phenomenon that is much more complex than information about pay. A worker will know much more about the pay in a new job than about the working conditions. Changing jobs mainly to improve working conditions is much more uncertain than changing to improve pay. Inversely, collective protest about working conditions gives some objectivity to the grievance (Gollac, 1997) and presses employers to take the problem into account and to respond with some improvements.

Whereas numerous empirical studies have been published in employment relations field using Hirschman's exit-voice theory (e.g. Freeman and Medoff, 1984; Miller and Mulvey, 1991), existing studies do not investigate empirically the direct influence of both working conditions and pay on the exit-voice strategy. Many studies have shown that by giving the opportunity of voice rather than that of exit, employers would benefit from a reduced turnover (e.g. Coutrot, 1998). But while quality is at the core of Hirschman's book (Barry, 1974; Dowding et al., 2000; Willman et al., 2009), this important aspect remains untested when the strategies of voice and exit are applied to the labour market.

Thus, the contribution of this paper is to fill the gap in the literature by examining the role of working conditions in shaping the exit-voice strategy. Our study gathers available data that can emphasize the generality of the theory and show that it does not depend on a specific institutional setting. While Hirschman's approach of consumers' voice went beyond the role of consumer movement in the US, such as that of Ralph Nader's, early transposition of Hirschman's theory to labour narrowed voice to unionization, especially the US form of unionization (Freeman and Medoff, 1984).

Therefore, testing Hirschman's theory in French and British contexts is an excellent case given that the involvement and influence of unions are not the same in both countries. In France, union delegates can engage in collective bargaining with the employer on behalf of all workers in the workplace through mandatory annual negotiations over wages and working time (Amossé and Forth, 2016). Hence, union representatives often receive support from nonunion members during social protests, and they also have the support of the legislation and access to union training funds (Andolfatto and Labbé, 2009). In Britain most unions seek to recruit an employee who will act as their local representative in negotiations with managers at the workplace. But in order to have an automatic right to recognition, unions should demonstrate membership among at least 50 per cent of employees in a bargaining unit (Amossé and Forth, 2016). In this case, the employer is obliged to negotiate with the union once a year over wages, working hours, and holidays (Amossé and Forth, 2016). Therefore, comparatively to France, union representatives in Britain rely more on workers membership and subscription fees and there's less incentive to free ride, which translates in higher union membership (27 per cent in UK versus 8 per cent in France in 2010). ${ }^{2}$ Therefore, unions' efficacy, density, and coordination with non-union members differ in the two institutional settings. Demonstrating that Hirschman's theory holds in both cases would show its generality.

For this study, we use French and British establishment panelized datasets that contain questions on quitting and participation in collective action over the preceding years: the British 2004 and 2011 WERS surveys, and the French 2005 and 2011 REPONSE surveys matched with administrative data on wages and labour flows in firms. ${ }^{3}$ We regress strikes on the one hand and quits on the other hand on past working conditions and pay. We show that one standard deviation of poor working conditions multiplies the probability of 
voice by 1.3 in France and 2.3 in Britain. Similarly, wages lower by one standard deviation increases the probability of quitting by a factor of 1.4 in Britain, and 1.5 in France.

The rest of the paper is organized as follows: the next section deals with previous research concerning the exit-voice trade-off and shows that the issue of working conditions was never fully addressed; the third section provides a more in-depth analysis of this tradeoff and sets up testable hypotheses; the fourth section presents the data and the method; the fifth section analyses the results; and the paper ends with a discussion on the scope and the limits of these results.

\section{Existing evidence and contribution to the literature}

A large and growing body of literature has transposed Hirschman's $(1970,1974)$ theory of consumer behaviour to labour relations' field. However, scholars have mainly focused on employees' trade-off between exit and voice and on its consequences, while the key notion of quality - which is the core element of Hirschman's model - was left aside.

Richard Freeman (1976, 1980); Freeman and Medoff, 1984) was the first to transpose Hirschman's framework to the labour market. Freeman and Medoff (1984) insisted that voice was a more efficient way of signalling poor working conditions than exit. However, they did not take into account heterogeneity in working conditions, and that this dispersion was a core determinant of the exit-voice arbitrage. They mainly focused on some consequences of the Hirschmanian mechanisms. When firms are unionized, unions provide a 'voice route' for expressing dissatisfaction and reduced the appeal for exit and therefore turnover (Freeman, 1980). Unions also increase wages and productivity and reduce inequality (Freeman and Medoff, 1984). These predictions have been confirmed at microlevel studies in Britain (Bryson and Forth, 2009; Bryson et al., 2013), in Australia (Miller and Mulvey, 1991), and to some extent in a comparative perspective between France and Britain (Coutrot, 1998).

While relating voice with unionization was an innovative contribution, which was routinely followed afterwards, it does not capture all forms of voice. In its original definition, Hirschman describes voice as a two-way communication between the organization (employer) and the consumer (employee), where the institutional element is not always necessary. Moreover, institutional mediation through unions (which follow multiple goals) may dilute the information that employees could want to transmit to their employers on their working conditions. Measure of employee direct voice might be a better measure of Hirschman's original mechanism. For instance Willman et al. (2009) show that there is a positive association between direct voice mechanisms and many desirable workplace outcomes. Although they highlight the importance of nonunion voice at work, they do not examine how employees react to a decline in working conditions.

The benefits of voice strategy have also been associated to improved motivation, commitment, and team working (Hammer, 2000). Scholars highlight the importance of studying direct worker participation as a voice mechanism in organizational decision-making processes, which should consequently influence the quality of work and contribute to organizational effectiveness. However, testing the impact of working conditions on direct voice remains still untested in these studies.

Extensive analysis of employee turnover has been carried out in labour economics to explain quitting behaviour. The negative link between level of pay and turnover was early 
posited by Adam Smith (1776) and repeatedly confirmed in empirical data (Clark, 2001; Freeman, 1978, 1980). But, even in Freeman's papers, this robust result was neither related to the exit-voice framework and to the type of information employees have on alternative options, nor compared to the relative impact of working conditions.

Many studies introduced job satisfaction scores as a quitting factor but without information on working conditions (e.g. Clark, 2001; Freeman, 1978; Kristensen and WestergardNielsen, 2006; Levy-Garboua et al., 2007; Shields and Price, 2002; Van Ophem, 1991). These studies show that job satisfaction is a powerful predictor of job quitting and that dissatisfied workers are more likely to separate from their jobs. An innovative contribution by Böckerman and Ilmakunnas (2006) shows that adverse working conditions increase the perception of job dissatisfaction and this in turn leads to actual quitting behaviour.

More recent studies started to take advantage of the availability of detailed data on workplace-specific attributes and introduce in the models individual and workplace job characteristics provided by the worker at the time of the survey (Cottini et al., 2011; Garcia-Serrano, 2004). For example Cottini et al. (2011) use Danish linked employer-employee data and show that hazardous working conditions contribute to higher voluntary quits but High-Involvement Work Systems reduce employee turnover. Although these studies contributed substantially to employee turnover literature by showing the relation between adverse working conditions or job dissatisfaction and quitting (Wood, 2008), they have not taken into account the strategy of voice, which could constitute an alternative strategy for doing so.

The review in the preceding paragraphs illustrates that there has been made valuable progress in investigating various effects of voice strategy on variables such as quit rates and workers' performance. To our knowledge no research has either surveyed or empirically explored the direct influence of working conditions relatively to pay on the exit-voice strategy. They were at best approached indirectly through work satisfaction or feelings of justice (Boroff and Lewin, 1997). Therefore, the current paper aims to investigate empirically the role of working conditions and pay in shaping the exit-voice strategy, and second to assess the consequences of those strategies on either pay increase or working conditions improvement.

\section{Expected findings}

The theoretical arguments are based on a more systematic specification of cost and benefit factors and of available information on wages and working conditions in alternative jobs, as well as on the comparative evaluation of the outcomes associated with the two alternatives: exit or voice.

\subsection{Workers coping with poor working conditions}

What do workers do when they are dissatisfied with working conditions? On the one hand, voice could seem more costly than exit, as it is costly to spend time and energy in order to influence a firm and obtain improvements. On the other hand, information on the quality of alternative options is poor and change is risky. 'From the perspective of workers, the information flow is especially likely to be faulty with respect to aspects of jobs, ranging from treatment by supervisors and coworkers to actual work responsibilities to evaluations of hazard, which cannot be calculated without actually accepting employment' (Freeman, 1976: 364). Workers 
not only face strong uncertainty on the distribution of working conditions, but they ignore their average. Therefore, they could estimate its expected levels in alternative jobs on the basis of that experienced in the current contract. Without alternative sources of information, subjective chances of improvement would then equate chances of degradation. While network contacts could increase the knowledge of working conditions distribution, given their embeddedness in workplaces and their homophilic nature (McPherson et al., 2001), they might not be sufficient to inform about the true distribution and to turn exit into a valuable to strategy to cope with poor working conditions jobs.

On the contrary, voice strategy conveys information to the firm and offers it a much more precise way to react to dissatisfaction than does exit. This will be especially the case when voice is expressed through participation in collective action. It goes then beyond each personal subjective appreciation of working conditions and gives much more objectivity to the claims. Chances of improvement are therefore positive.

For consumer markets, Hirschman (1970) argues that buyers will favour voice for more complex goods (such as schooling) and complex quality problems (such as car security issues). In such cases, information disclosed on quality when the deal is done is only a small proportion of overall information on quality. In the labour market, the cost of trying a new job in order to improve its quality is generally more substantial than for most consumer goods, both because working conditions are generally more complex than the quality of a good and because it cannot be assumed to be stable.

Moreover, Hirschman (1970) argues that the voice option is the more often chosen when exit is difficult, costly, and unavailable. Therefore, if employees do not have other exit options - because of the local rate of unemployment, for instance - they will use more voice to inform on the decline of working conditions.

Hirschman's argument does not suggest that dissatisfaction with working conditions will never lead to the choice of exit by employees. In some situations, the cost of voice is too substantial and disclosed information about the quality of alternative options is sufficient to make exit a valuable strategy. Hirschman's argument implies rather that the internalization of the costs and the benefits of exit and voice make the voice strategy a more likely one than the exit strategy on the whole.

We thus formulate our first hypothesis:

H1: Poor working conditions favour collective voice.

\subsection{Workers coping with low pay}

Let us now discuss the strategies adopted by those who are dissatisfied with their pay. The complexity of the labour market, the imperfection of information, the magnitude of transaction costs, and the decentralization of the labour market lead to a multiple price equilibrium (MacLeod and Malcomson, 1993). The wage offered for the same job and the same worker characteristics is not unique and can be viewed as a statistical distribution. Workers who ceteris paribus earn lower wages are more likely to find rival offers that will improve their wage among other firms. Inversely, those with higher wages are less likely to find better offers.

Contrary to employees dissatisfied with their working conditions, employees dissatisfied with their pay generally have information about the salary offered by other jobs. For instance Acemoglu (2001) argues that workers generally benefit from information about which industries pay higher wages. Furthermore, while employees may not have 
information about working conditions in the recruiting firm, pay is generally the first informational element that will be disclosed and discussed during recruitment. This simple statistical phenomenon enables us to formulate our second hypothesis.

H2: Low pay favours exit.

\section{Methods}

\subsection{Data}

We use the British Workplace Employment Relations Survey (WERS 2004 and 2011) and the French Enquête Relations Professionnelles et Négociations d'Entreprise (REPONSE 2005 and 2011).

Both surveys are considered to be the most authoritative sources of information on employment relations in France and in Britain and cover a range of topics relating to both employers and employees. The surveys provide a broad range of topics that are of central interest in employment relations, including multiple dimensions of working conditions, collective action, and pay. The WERS survey is representative of all workplaces with five or more employees in Britain. It covers all industries in both private and public sector excluding workplaces in agriculture, forestry and fishing, and mining and quarrying. The survey population for all establishments in REPONSE (2005) contains 21 or more employees, and in REPONSE (2011) eleven and more employees with 15 months of tenure. REPONSE covers only private and semi-public firms and excludes public sector and agriculture.

Both the REPONSE and WERS surveys included a panel dimension enabling to measure lagged variables. An important fraction of establishments (989 in the WERS survey and 872 in the REPONSE survey ${ }^{4}$ ) surveyed in 2005 were also interrogated in the following edition. One limitation of both surveys is that the responding employees at each wave are not necessarily the same. The Appendix Table A1 presents the reduction in sample size once the panel at the workplace level is matched with the employee survey.

There is no direct information in the REPONSE survey on the number of entries and exits from employment. Therefore, in order to measure exit strategies, we matched the REPONSE survey with the DMMO survey 2006 (Déclaration Mensuelle de Mouvements de Main-d'Oeuvre), which details gross establishment labour and job flows, and with the EMMO survey (2006) (Enquête sur les Mouvements de Main d'Oeuvre), a quarterly survey of entries and exits from employment. DMMO-EMMO (2006) surveys contain information on voluntary exits from employment that we use for the rate of exit variable (number of voluntary exits in 2006 divided by the total number of employees). As not all establishments in the DMMO-EMMO (2006) database are present in the REPONSE panel, the sample size was reduced to 597 establishments.

For the robustness check we also use another French survey, Les Salaires vus par les Salariés (SalSa 2009) presented in more details in Appendix B, for which we provide below the main results related to exit and pay.

\subsection{Voice and exit variables}

While most studies have used union presence, union membership or collective bargaining coverage as the main measure of voice, these variables appear to be a partial and imperfect 
measure of the direct implication of employees in voicing activity (Bryson, 2004; Bryson et al., 2013). In order to overcome the dilution of voice in institutional union intermediation, we selected the variable that reflected employees' direct implication in voicing activity such as strikes or industrial actions. Although voicing may not be necessarily confrontational, the confrontational ones are more likely to be recorded and have the advantage of witnessing a substantial level of implication. However, we also checked that union coverage or membership yielded similar results.

We also consider the discussion on 'employment issues' in meetings between managers and workers as a channel for expressing individual dissatisfaction with working conditions. However, the formality of these meetings and the asymmetry of the workers-managers could weaken its efficacy compared to spontaneous protests where the collective dimension gives objectivity to the grievance. We will therefore compare collective voice channel with individual voice channel.

In order to capture exit, we use variables on voluntary job quitting. Therefore, we exclude non-voluntary labour flows such as layoffs or retirements which follow a different logic.

Depending on the dataset, information on voice and exit are either recorded at the individual level or at the establishment level.

In the WERS (2011) survey, the strategies of voice and exit are captured by establishment level variables. The managers were asked to report which forms of industrial action had taken place at the workplace during the previous 12 months: strikes of less than a day, strikes of a day or more, overtime ban or restriction, or work to rule. Other voice variables are also available like disputes, threat of strikes, ballots, disruption, application at employment tribunal, number of unions or staff association with members in the workplace, and individual membership in a union or staff association (Table 1). We use also variables on individual voice channels such as regular meetings between managers and the workforce. Our main voice variable is the occurrence of a strike during the last 12 months (as the combination of strikes of less than a day and those of a day and more). This collective action took place in 17 per cent of the workplaces between 2010 and 2011 in the WERS panel.

In the WERS survey, we also calculated the exit rate for the 2011 establishments. Managers were asked to report the number of employees who had voluntarily left or resigned the workplace in the previous 12 months as well as the number of employees they had on the payroll at the workplace in 2011. The exit rate at the workplace level in 2011 was therefore calculated as the ratio of those two last tables. The average turnover rate among WERS workplaces was 8 per cent in 2010 and 2011 (Table 1). ${ }^{5}$

In the REPONSE survey (2011), the voice variable was measured both at the workplace and at the individual level. At the workplace level, managers were asked to report which forms of dispute their establishments had experienced in the past 3 years (2008-10): stoppage, strikes of less than 2 days, strikes for more than 2 days, go-slow strike, work-to-rule, slowdown of production, refusal to work overtime, assembly, demonstration, and petition (Table 2). Stoppage and strikes of less than 2 days appear to be the most common strategies. At the establishment level, information is also provided on the presence of union delegate and the occurrence of employee application to an Employment Tribunal. In the employee survey, employees were asked whether or not they are union members, and whether or not they participated in a work stoppage. Regular meetings and institutionalized discussions on working condition serve as proxies for individual voice channels.

Finally, our two main voice variables will be, at the establishment level, the occurrence of a strike in the workplace between 2008 and 2010 (which happened in 33 per cent of the workplaces) and at the individual level, the participation in a strike ( 22 per cent of the workers did 
Table 1. Voice and exit strategies in the 2011 WERS survey

Which, if any, of the forms of industrial action on this card have taken place at this workplace during the last 12 months?

1. Strikes of less than a day

2. Strikes of a day and more

3. Strikes

4. Overtime ban or restriction by employees

5. Work to rule

$\begin{array}{cc}\text { Yes } & \begin{array}{c}\text { On how many } \\ \text { occasions } \\ \text { (per cent) }\end{array} \\ \text { (if Yes) }\end{array}$

2.6

15

17

2.1

3.5

$\begin{array}{ll}1.35 & 767 \\ 1.37 & 767 \\ 1.40 & 767 \\ 4.53 & 767 \\ 3.00 & 767\end{array}$

\section{Other voice variables}

Yes N. Obs.

6. In the last 12 months, has there been a collective dispute with any group of workers over pay or conditions?

7. In the last 12 months, have any employees here threatened to start a strike?

8. In the last 12 months, have any unions here balloted their members to establish the level of support for industrial action?

9. In the last 12 months, has this workplace suffered significant disruption as a result of industrial action in another organization?

10. During the last 12 months has an employee or ex-employee of this workplace made an application to an Employment Tribunal?

11. At least one union or staff association having members in the workplace

12. Regular meetings between line managers and all the workers they manage

13. Regular meetings between senior managers and the whole workforce

14. Individual membership in a union or a staff association

\begin{tabular}{rr}
17 & 769 \\
14 & 767 \\
24 & 760 \\
2.9 & 770 \\
& \\
25 & 763 \\
& \\
65 & 760 \\
87 & 772 \\
& \\
83 & 772 \\
39 & $7282^{\mathrm{b}}$ \\
\hline
\end{tabular}

\begin{tabular}{lccccc}
\hline & $\begin{array}{c}\text { Mean } \\
\text { (per cent) }\end{array}$ & $\begin{array}{c}\text { Std. Dev. } \\
\text { (per cent) }\end{array}$ & $\begin{array}{c}\text { Min } \\
\text { (per cent) }\end{array}$ & $\begin{array}{c}\text { Max } \\
\text { (per cent) }\end{array}$ & N. Obs. \\
\hline 15. 2011 Workplace voluntary exitrate & 8.0 & 11 & 0.0 & 86 & 714 \\
\hline
\end{tabular}

Note: Both private and public sector workplaces that were surveyed both in 2004 and 2011. In bold, the key variables used for the analysis of voice and exit.

Source: WERS (2004-11).

${ }^{\mathrm{a}}$ Observations are establishments except line 12.

${ }^{\mathrm{b}}$ Where they are employees.

so). These two voice variables are complemented by our main exit variable, the average turnover rate among REPONSE workplaces, which amounts to 4.3 per cent (Table 2).

As expected by previous literature (Freeman, 1980; Freeman and Medoff, 1984), we find a strong negative correlation between exit and voice strategies in the two surveys at the establishment level (Table 3). The exit rate is lower in the workplaces where collective action happened than in the workplaces where it did not occur.

\subsection{Poor working conditions variable}

Hirschman's (1970) theory is concerned with perceptions of individuals rather than absolute measures. Thus, in this study we measure perceptions of employees with regard to 
Table 2. Voice and exit strategies in the REPONSE survey

\begin{tabular}{lccccc}
\hline $\begin{array}{l}\text { Which types of conflicts did it } \\
\text { happen in the establishment } \\
\text { between 2008 and 2010? }\end{array}$ & $\begin{array}{c}\text { More than } \\
\mathbf{5} \text { times } \\
\text { (per cent) }\end{array}$ & $\begin{array}{c}\text { From } \mathbf{3} \text { to } \\
\mathbf{5} \text { times } \\
\text { (per cent) }\end{array}$ & $\begin{array}{c}\text { From once } \\
\text { to twice } \\
\text { (per cent) }\end{array}$ & $\begin{array}{c}\text { Never } \\
\text { (per cent) }\end{array}$ & N. Obs. \\
\hline 1. Stoppage & 11 & 6 & 14 & 68 & 795 \\
2. Strikes of less than 2 days & 9 & 7 & 13 & 71 & 795 \\
3. Strikes of more than 2 days & 1 & 1 & 7 & 90 & 795 \\
4. Go-slow strike & 0 & 0 & 2 & 98 & 795 \\
5. Work-to-rule, slowdown & 1 & 1 & 2 & 96 & 795 \\
6. Overtime ban & 3 & 2 & 4 & 91 & 795 \\
7. Assembly, demonstration & 6 & 4 & 12 & 77 & 795 \\
8. Petition & 2 & 4 & 20 & 75 & 795 \\
\hline
\end{tabular}

Other voice variables in 2011

Yes

(per cent) N. Obs.

9. At least one strike in the establishment (constructed out of 2 and 3 )

10. Employee making an application to an Employment Tribunal

11. Presence of a union delegate in the establishment

12. Individual participation between 2008 and 2010

33

$33 \quad 795$

$52 \quad 795$

$68 \quad 795$

in a work stoppage or a strike

13. Individual union membership

14. Regular workshop, office, or service meetings

15. Discussions or negotiations between firm and employees on working conditions

$22 \quad 2579^{\mathrm{b}}$

$13 \quad 2579^{\mathrm{b}}$

$88 \quad 795$

$39 \quad 795$

\begin{tabular}{lccccc}
\hline & $\begin{array}{c}\text { Mean } \\
\text { (per cent) }\end{array}$ & $\begin{array}{c}\text { Std. Dev. } \\
\text { (per cent) }\end{array}$ & $\begin{array}{c}\text { Min } \\
\text { (per cent) }\end{array}$ & $\begin{array}{c}\text { Max } \\
\text { (per cent) }\end{array}$ & N. Obs. \\
\hline 16. 2006 establishment voluntary exit rate & 4.3 & 6.0 & 0.0 & 62 & $597^{\mathrm{c}}$ \\
\hline
\end{tabular}

Note: Private sector workplaces that were surveyed both in 2005 and 2011. In bold, the key variables used for the analysis of voice and exit.

${ }^{\mathrm{a} O}$ Observations are establishments surveyed in both years except lines 12 and 13 .

${ }^{\mathrm{b}}$ Where they are employees. In lines 12 and 13 we use the 2011 employee survey.

${ }^{\mathrm{c}}$ Observations are establishment - level based on the DMMO-EMMO survey.

Source: DARES, REPONSE (2005-11), DMMO-EMMO (2006).

Table 3. Exit voice trade-off. Variation of exit rate depending on the use of voice strategy

\begin{tabular}{|c|c|c|c|c|c|}
\hline Workplace recently voicing: Survey & Yes & No & $\Delta T$. Test & N. Obs. & Corr. coeff. \\
\hline $\begin{array}{l}\text { WERS: } 2011 \text { workplace exit rate depending } \\
\text { on strikes declared in } 2011\end{array}$ & 4.5 & 8.7 & $* * *$ & 710 & $-0.14^{* * *}$ \\
\hline $\begin{array}{l}\text { REPONSE: } 2006 \text { workplace exit rate depending } \\
\text { on strikes declared in } 2011 \text { at the } \\
\text { establishment level }\end{array}$ & 2.6 & 5.4 & $* * *$ & 597 & $-0.23^{* * *}$ \\
\hline
\end{tabular}

Source: WERS (2004-11); REPONSE (2005-11).

*** Statistically significant at the 0.01 level.

their working conditions. There are some disagreements among scholars with regard to the definition and measurement of this concept (Osterman, 2013; Sen Gupta et al., 2009). Proponents of the subjective approach focus on workers' responses with regard to their 
satisfaction levels with different aspects of work (Clark, 2011; Stride et al., 2007), whereas proponents of the objective approach suggest defining well-being of individuals in relation to 'capabilities' of achieving certain things (Sen, 1999). Although each approach has its own pros and contras (Brown et al., 2012; Cooke et al., 2013; Sehnbruch, 2004), there is a consensus in the literature on the multi-dimensional nature of job quality (Davoine et al., 2008; De Bustillo et al., 2011; Green et al., (2013).

The two surveys ask somewhat different questions about particular working conditions. In deciding which dimensions of work to include in the analyses, we examined which questions capture poor working conditions of employees. Our measures of poor working conditions integrate both objective and subjective dimensions of job quality depending on the survey used. We also built a composite variable of poor working conditions as it offers the opportunity of comparing responses across surveys in a relatively simple way.

In the WERS (2004) survey, we use the following variables to build the index of poor working conditions: 'My job requires that I work very hard' (Strongly agrees or agrees: 75 per cent), 'I never seem to have enough time to get my work done' (Strongly agrees or agrees: 41 per cent), 'In general, how much influence do you have' on 'the order in which you carry out tasks' (Little or none : 26 per cent), 'on how you do your job' (Little or none: 15 per cent), 'Satisfaction with the work itself' (Very dissatisfied or dissatisfied: 9 per cent), 'How much of the time the job made you feel tense over the last few weeks' (All or most of the time: 19 per cent), 'Relations between managers and employees here' (Very poor and poor: 15 per cent).

The addition of these items (as listed above in italics) enables us to build an index of poor working conditions. ${ }^{6}$ In order to give equal importance to each item in the variance of the index, we standardized each of them, as well as the sum of items. This individual measure of poor working conditions is then averaged at the establishment level.

The 2005 REPONSE employee survey does not have very detailed questions on objective working conditions but provides a global question that can be interpreted as a global subjective evaluation. 'Do working conditions limit your involvement at work'? Yes absolutely (23 per cent), yes somehow (33 per cent), not really (26 per cent), not at all (17 per cent). We use this four scale ordinal variable as a continuous one (ordered from good to bad conditions). We further average this scale at the workplace for establishment level regressions.

\subsection{Pay variable}

In the 2004 WERS survey, employees declare their weekly pay and their number of hours out of which we computed the hourly pay. ${ }^{7}$ We standardized the variable at the individual level and then we calculated the mean of the log hourly wage (2004) for each establishment in the panel.

Pay in the REPONSE survey is imported from the DADS (2003 and 2009), an administrative file devoted to the calculation of social contributions. This file contains both yearly wages and yearly number of hours and enables to calculate hourly wages. REPONSE 2005 survey was matched with DADS 2003 and REPONSE 2011 with DADS 2009.

\subsection{Other control variables}

Based on data availability, we use gender, tenure, age, number of working hours, education, occupation, workplace size, and industry as control variables in both surveys. When 
the voice or exit strategy variable is defined at the establishment level, we use the means of the individual variables by establishment. All the control variables are measured in 2004 (WERS) or 2005 (REPONSE) prior to the measure of the voice or exit strategies.

The descriptive statistics of the controlled variables can be found in the Appendices (A4 for the WERS survey, A5 for the REPONSE survey).

\section{Model}

We explore the links between poor working conditions and pay in $t-1$ and the strategy declared in $t$ and that occurred sometime between $t-1$ and $t$. Therefore, the basis model that we want to estimate can be written in the following form:

$$
P\left(Y_{t}=1\right)=f\left(b_{0}+b_{1} \cdot \mathrm{PWC}_{t-1}+b_{2} \cdot \log \left(w_{t-1}\right)+\ldots+b_{k} \cdot x_{k,(t-1)}+\ldots+u\right)
$$

where $Y_{j}$ represents the strategy variables at time $t, \log \left(w_{t-1}\right), \mathrm{PWC}_{t-1}$ and $x_{k(t-1)}$ are, respectively, log hourly pay, the index of poor working conditions and control variables at time $t-1$. When the dependent variable is dichotomous, we estimate our models with logistic regressions (and $f$ stands for the logistic function). When it is an establishment average rate (as for exit variables), we use OLS regressions (and $f$ stands for the identity function). We estimated here unweighted regressions. However, our control variables include the size of the establishments and industry, two variables that served in WERS and REPONSE for the initial sampling of the surveyed establishments. ${ }^{8}$

It is critical in this model that pay and poor working conditions are not measured after the strategy (either exit or voice) occurred. Otherwise we could face a bias due to reverse causality, as employees' strategy impacts in return pay and working conditions.

This condition is clearly respected thanks to establishment panelized surveys in WERS and REPONSE, which enable to use at the establishment level 2005 working conditions and pay. Nevertheless establishment level regressions might be biased by ecological fallacy. One could imagine, for instance strikes to occur in establishment with poor working conditions. But it might be possible that employees who participate in strikes are only the ones with good working conditions. Although this mechanism is not very likely, a confirmation of establishment results at the individual level is very welcome.

\section{Results}

The OLS and Logit models in Table 4 indicate whether poor working conditions or pay are significantly related to strategies of exit and voice. Only variables of interest are reported, and they are standardized in order to measure the impact of a one standard deviation increase on the occurrence of the strategy. Full regressions of our main models (1, 2, 3, and 4) can be found in Appendices (Tables A4, A5).

\subsection{Poor working conditions and strategies}

Our first hypothesis stated a positive impact of poor working conditions on collective action. It is confirmed in all models both at the workplace and at the individual level. One standard deviation of our poor working conditions index multiplies the probability of 
Table 4. Impact of pay and of poor working conditions on workers' strategies

\begin{tabular}{|c|c|c|c|c|}
\hline \multirow[b]{2}{*}{ WERS - Establishment level } & \multicolumn{2}{|c|}{$\begin{array}{c}\text { Collective } \\
\text { action in } 2010\end{array}$} & \multicolumn{2}{|c|}{$\begin{array}{l}\text { Exit } \\
\text { in } 2010\end{array}$} \\
\hline & Model 1 & & Model 2 & \\
\hline $\begin{array}{l}2004 \text { Poor working conditions } \\
\text { (establishment mean) }\end{array}$ & $0.87 * * *(0.31)$ & {$[2.34]$} & $0.62(0.80)$ & [1.09] \\
\hline $\begin{array}{l}2004 \text { Log hourly wage (establishment } \\
\text { mean of log pay) }\end{array}$ & $0.01(0.35)$ & {$[1.20]$} & $-2.10 * *(0.93)$ & {$[1 / 1.40]$} \\
\hline Pseudo R2 (logistic) or R2 (OLS) & 0.41 & & 0.25 & \\
\hline Number of observations (i.e. establishments) & 759 & & 706 & \\
\hline Model & Logit & & OLS & \\
\hline
\end{tabular}

Collective action

Exit

in 2008-10

in 2006

\begin{tabular}{|c|c|c|c|c|}
\hline REPONSE - Establishment level & Model 3 & & Model 4 & \\
\hline $\begin{array}{l}2005 \text { Poor working conditions } \\
\text { (establishment mean) }\end{array}$ & $0.28 * *(0.13)$ & {$[1.33]$} & $\begin{array}{l}0.42 \\
\quad(0.30)\end{array}$ & [1.10] \\
\hline $\begin{array}{l}2003 \text { Log hourly wage } \\
\text { (establishment mean) }\end{array}$ & $0.67 * * *(0.19)$ & {$[1.96]$} & $-1.39 * * *(0.45)$ & {$[1 / 1.51]$} \\
\hline Pseudo R2 (logistic) or R2 (OLS) & 0.22 & & 0.32 & \\
\hline Number of observations (i.e. establishments) & 795 & & 590 & \\
\hline Model & Logit & & OLS & \\
\hline REPONSE - Individual level & Model 5 & & & \\
\hline $\begin{array}{l}2005 \text { Poor working conditions } \\
\text { (establishment mean) }\end{array}$ & $0.22 * * *(0.08)$ & {$[1.24]$} & & \\
\hline $\begin{array}{l}2003 \text { Log hourly wage } \\
\text { (establishment mean) }\end{array}$ & $0.49 * * *(0.08)$ & {$[1.62]$} & & \\
\hline Pseudo R2 & 0.14 & & & \\
\hline Number of observations (i.e. workers) & 2393 & & & \\
\hline Model & Logit & & & \\
\hline
\end{tabular}

Notes: Parameters are $\times$ standardized. Odds ratios are displayed in square brackets. For least squares regressions (models 2,4 ), we calculate the odds ratios by comparing the average proportion $p$ and $\left[p+\beta_{x} \cdot \operatorname{sd}(x)\right]$ the deviation according to the model when one standard deviation of the interest variable is added. For easing comparisons of magnitudes, we print odds ratio below 1 as fractions. The coefficients in models 2, 4, and 7 are presented in percentage points.

Control variables in all models include working hours (simple and squared), age (simple and squared), size of the establishment, gender, occupation, diploma, and industry. In WERS and REPONSE models, we also used tenure (simple and squared). In all establishment level models, we use establishment average of the control variables. In individual level models, we use individual variables. Control variables are not reported here but can be found in Tables A4 and A5. Table A3 provides descriptive statistics and first order correlations of our key variables.

$* *$ Statistically significant at the 0.05 level; ***at the 0.01 level.

involvement in a strike in the following years by a factor of 2.3 in the WERS survey and 1.3 in REPONSE survey. To give a further intuition of the magnitude of the effect, based on our estimates, we can calculate that in Britain, within a twelve-month period, strikes occur at least once in 33 per cent of the establishments whose working conditions are one standard deviation worse than the mean and in 8 per cent of the establishments where it is one standard deviation better. In France, within a three-year period, these tables are, respectively, 39 per cent for one standard deviation below and 27 per cent for one standard deviation above. 
Previous results clearly hold at the establishment level. We are also able to test the role of working conditions at the individual level in REPONSE. In REPONSE, establishment working conditions in $t-1$ clearly impact the individual probability of voicing afterwards (model 5), by a factor of 1.2. ${ }^{9}$

We also checked the robustness of our result by testing the impact of poor working conditions on other voice variables (Table 5). The results are very robust. Poor working conditions always have a positive effect on the most frequent voice variables such as in Britain (Table 5, Panel A) strikes of less than a day (by a factor of 3.2), strikes of a day and more (by a factor of 2.2), ballots (by a factor of 2), actions in Employment Tribunal (by a factor of 1.6), unions presence (by a factor of 2.2), and individual union membership (by a factor of 2.2). Some British communication channels like meetings between line managers and subordinates are significantly correlated with poor working conditions, as well as the discussion of employment issues (Table 5 models 12 and 14). These meetings between employers and employees appear to provide an information channel to workers to express their dissatisfaction with regard to working conditions.

In France (Table 5, Panel B), poor working conditions favour participating in stoppage by a factor of 1.4, in strikes for less than 2 days by a factor of 1.3 , in strikes for more than 2 days by a factor of 1.5 , in go slow strike by a factor of 2 , in assembly, demonstration by a factor of 1.5 , in petition by a factor of 1.4 or is linked to the presence of a union delegate by a factor of 1.3. They are not correlated with channels of discussion within the workplace. However, we find a significant and logical correlation between poor working conditions and negotiation on this issue.

The results based on voice models show that poor working conditions have a positive and significant impact on the probability of participating in collective action. On the contrary, poor working conditions do not appear to be significant in the exit models. Although they impact positively and significantly on intentions to quit (Table A6, models 7-10), they do not influence the effective exits. When we compare the odds ratios in both models the odds are higher in voice models than in exit ones: in the WERS survey 2.3 compared to 1.1 (Table 4, models 1 and 2); in the REPONSE survey 1.4 compared to 1.1 (Table 4, models 3 and 4). These findings are coherent with our Hirschmanian framework; therefore, we consider that our hypothesis $\mathrm{Hl}$ holds.

We also checked for the heterogeneity of the impact of working conditions on voice, along five dimensions: part-time work, age (above 30), tenure (more than 5 years), blue collar work, and female. The intensity of the working conditions effect did not vary significantly in establishments where the proportion of the latter variables was higher. ${ }^{10}$

\subsection{Pay and strategy}

Let us now turn to the examination of the impact of pay on strategies. In all the exit models, log hourly pay has a negative and statistically significant impact on quitting. A pay lower by one standard deviation ${ }^{11}$ multiplies the probability of exit by a factor of 1.4 in the WERS survey, 1.5 in the REPONSE survey (Table 4). ${ }^{12}$ To put it differently, when wages decline by 10 per cent, the establishment exit rate is multiplied, respectively, by 1.06 in WERS, 1.08 in REPONSE. These results hold both at the establishment level (WERS, REPONSE) and at the individual level in SalSa, where we can use information on pay in 2003, before the strategy is adopted (Table A6 in appendix). As previously, we also checked those results for heterogeneity in the impact of pay on exit and we did not find any meaningful variation. 
Table 5. Robustness check: variation in voice variables

\begin{tabular}{|c|c|c|c|c|}
\hline \multirow[b]{2}{*}{$\downarrow$ Dependent variables in $t$} & \multirow[b]{2}{*}{$\begin{array}{l}\text { Mean prop. } \\
\text { (per cent) }\end{array}$} & \multicolumn{2}{|c|}{ Independent variables in $t-1$} & \multirow[b]{2}{*}{ N. Obs. } \\
\hline & & $\begin{array}{l}\text { Poor working } \\
\text { conditions }\end{array}$ & $\begin{array}{c}\text { Log of } \\
\text { hourly pay }\end{array}$ & \\
\hline \multicolumn{5}{|l|}{ Panel A. WERS } \\
\hline 1. Strikes of less than a day & 3 & $3.18 * *$ & 2.05 & 759 \\
\hline 2. Strikes of a day and more & 15 & $2.16^{* *}$ & 0.93 & 759 \\
\hline 3. Overtime ban or restriction by employees & 3 & 1.88 & 0.41 & 759 \\
\hline 4. Work to rule & 4 & 2.56 & $0.19 *$ & 759 \\
\hline 5. Dispute & 17 & 1.46 & 0.84 & 761 \\
\hline 6. Threat of strike & 14 & 1.34 & 1.12 & 759 \\
\hline 7. Ballot & 24 & $1.97 * * *$ & $2.1 * *$ & 752 \\
\hline 8. Disruption & 3 & 1.48 & 1.14 & 762 \\
\hline $\begin{array}{l}\text { 9. Employee making an application to } \\
\text { an Employment Tribunal }\end{array}$ & 25 & $1.60 * *$ & $1.8^{* *}$ & 755 \\
\hline $\begin{array}{l}\text { 10. At least one union or staff association } \\
\text { having member in the workplace }\end{array}$ & 65 & $2.16^{* * *}$ & 1.28 & 752 \\
\hline $\begin{array}{l}\text { 11. Individual membership in a union or } \\
\text { a staff association }\end{array}$ & 39 & $2.16^{* * *}$ & $1.39 * * *$ & 6909 \\
\hline $\begin{array}{l}\text { 12. Meetings between line managers and } \\
\text { all the workers they manage }\end{array}$ & 87 & $2.79 * * *$ & $3.03 * * *$ & 764 \\
\hline $\begin{array}{l}\text { 13. Meetings between senior managers } \\
\text { and the whole workforce }\end{array}$ & 83 & 1.10 & 1.18 & 764 \\
\hline \multicolumn{5}{|l|}{ Panel B. REPONSE } \\
\hline 15. Stoppage (at least once) & 31 & $1.39^{* *}$ & $1.85^{* * *}$ & 795 \\
\hline 16. Strikes less than 2 days (at least once) & 29 & $1.34^{* *}$ & $1.89 * * *$ & 795 \\
\hline $\begin{array}{l}\text { 17. Strikes of more than } 2 \text { days } \\
\text { (at least once) }\end{array}$ & 10 & $1.48^{*}$ & $2.39 * * *$ & 795 \\
\hline 18. Go-slow strike (at least once) & 2 & $2.07 *$ & 1.64 & 795 \\
\hline 19. Work-to-rule, slowdown (at least once) & 4 & 1.17 & $2.02 *$ & 795 \\
\hline 20. Refusal to work overtime (at least once) & 9 & 1.34 & 1.18 & 795 \\
\hline 21. Assembly, demonstration (at least once) & 22 & $1.51^{* * *}$ & $1.76^{* * *}$ & 795 \\
\hline 22. Petition (at least once) & 25 & $1.35^{* *}$ & $1.48^{* *}$ & 795 \\
\hline $\begin{array}{l}\text { 23. Employee making an application to } \\
\text { an Employment Tribunal }\end{array}$ & 51 & 0.95 & 1.11 & 795 \\
\hline $\begin{array}{l}\text { 24. Presence of a union delegate } \\
\text { in the establishment }\end{array}$ & 68 & $1.34 * *$ & $1.77 * * *$ & 795 \\
\hline 25. Individual union membership & 11 & 1.08 & $1.19^{*}$ & 2364 \\
\hline $\begin{array}{l}\text { 26. Regular workshop, office, or } \\
\text { departmental meetings }\end{array}$ & 88 & 0.98 & 1.28 & 795 \\
\hline $\begin{array}{l}\text { 27. Discussion or negotiation between firm } \\
\text { and employees on working conditions }\end{array}$ & 69 & $1.28 * *$ & 1.08 & 795 \\
\hline
\end{tabular}

Notes: Each line corresponds to a different logistic regression. Parameters are $\mathrm{x}$ standardized. We display here parameters' odds ratios. Control variables similar to Tables A2-A4 are not reported. In Panel A and B, $t=2011$ and $t-1=2004$ or 2005 .

*Statistically significant at the 0.10 level; **at the 0.05 level; ***at the 0.01 level.

Coherently, low pay has a stronger impact on the probability of quitting for a pay increase than on quitting for other reasons (Table A6 in appendix). It has also a similar impact on intention of quitting, especially related to pay issues and on the exit that happened during the following year (2009) (the small number of exits in 2009 shrinks here significance). 
We have explained why exit could be more effective than voice for increasing pay considering the collective cost of the latter and the uncertainty of its result. In fact, it is not workers with the lowest wages who use their voice the most. Voice is rather associated with higher wages in France (Table 4, models 3, 4). This result is also confirmed in different types of collective action models: stoppage, strikes of less than 2 days, strikes of more than 2 days, slowdown, overtime ban and demonstration (Table 5). This finding is in line with classical research on industrial relations showing that unions and collective action develop in industries that are protected from competition and that can therefore attribute higher wages (Dickens and Katz, 1987). A simple comparison of the negative significant impact of pay on exit and its positive significant impact on voice shows that our results are compatible with $H 2$.

Following these results on the determinants of exit and voice, one could finally propose a different interpretation, especially for France, of the early correlation between poor working conditions and voice, within the traditional framework of collective action based on bargaining power and on the degree of competition (Budd, 2005). In industries protected from competition, workers can raise wages through voice strategies. Firms could react in return to those high wages by letting working conditions progressively deteriorate, which could seem compatible with the main correlations described in Tables 4 and 5. However, when we introduce variables tracking the degree of competition in WERS or REPONSE (as in Van Wanrooy et al., 2013), this does not modify substantially our results (cf. Table A7 in appendix). Therefore, we feel confident that we do not capture a reverse causality phenomenon. ${ }^{13}$

\section{Discussion}

To our knowledge, this contribution is the first detailed application to the labour market of Hirschman's exit-voice framework that puts working conditions at the centre of the exit-voice trade-off. It provides the main reasons why poor working conditions tend to favour voice strategies and low pay tends to favour exit strategies. Our main statistical findings support this framework: a deterioration in the index of poor working conditions increases the probability of participation in collective action in the two surveys. An increase in log hourly wage decreases the probability of quitting.

However, our first results need further confirmation with other datasets and alternative research designs. Using a natural experiment, such as exogenous random shocks on pay and working conditions, would probably constitute the best test of the theory. Unfortunately, those shocks are generally difficult to find and might remain context dependent. A more feasible way of improving our study would be to have a richer linked employer-employee panel dataset. A first improvement would be to rely on measures of working conditions that are both more encompassing - either through a rich set of objective questions on a variety of job characteristics or through an all-in-one question such as working condition satisfaction - and more comparable from one issue to another. Second, voice, exit, working conditions, and pay should be measured both at the individual and workplace level. Third, having at our disposal a panel of both workplaces and individuals during more than two periods (at least three) would help to study more precisely the dynamic of changes in working conditions and pay, and changes in voice and exit, and to estimate change models with establishment fixed effect. With only two periods, the delay in recording the voice events (from one to 5 years prior to the survey used) makes it difficult to 
measure the impact of the change in working conditions on the change in voice (as in Bryson et al., 2017), because we do not know the order of the changes. With three periods, statistical inference in this domain and the study of reverse causality would be substantially facilitated. Finally, matching these surveys to administrative dataset containing workers' wage and employment history could help to solve the problem of sorting of workers to specific workplaces with specific working conditions, pay, unionization, and turnover characteristics (Bockerman et al., 2012). We hope that future surveys on working conditions and on the structure of earnings in Europe will enable researchers to progress in this direction.

A future step in this research would be to study the dynamic consequences of the exit-voice arbitrage. In Hirschman's framework, for the most complex goods such as the quality of education, voicing provides detailed information than exit, and permits an improvement in quality (Hirschman, 1974). Transposed to the labour market, this would mean that complaints over working conditions would favour their improvement. Here and there, a person individually voicing on its working condition could obtain a personal improvement. However, the lack of generality of the grievance might undermine its objectivity and downplay efforts for improvements. Moreover, workers might individually overlook the poor working conditions they face. For instance in France, nurses' social protests of the mid 1980s helped them to recognize that they 'handle heavy loads' at work (Gollac, 1997). Quite often, poor working conditions nourish an individual dissatisfaction with pay (Godechot and Gurgand, 2000) and claims for higher wage compensation. On the opposite, collective voice contributes to a double objectification of poor working conditions, both for the workers and the employers. Collective voice would then have a public good dimension, by improving working conditions not only for protesters but also for other workers, including future ones. However, workers and firms could prefer to bargain over compensating differentials (Rosen, 1986), rather than 'solving' workplace problems. Indeed, although poor working conditions pushes workers to go on strikes, most of strikes in France and Britain finally coalesce around pay increase claims. Some difference in the institutional settings might here make a difference. While in France work quality remained stable and low, in the United States, judicialization of work relations, responsibilization of employers and involvement of unions favoured in the 1990s a global improvement of working conditions and a decline in work-related accidents (Askenazy, 2004). Unfortunately, the WERS and REPONSE data exploited for this article lack depth and robustness for exploring the dynamic return of voice on labour quality. Future research should therefore address this critical point.

Finally, if our results and theoretical framework hold true, they could be an invitation to revise our views on collective action. Our study challenges two traditional views about collective action. The market view sees collective action as relatively inefficient and even when it leads to improvements for workers, it does so at the cost of deviating from market equilibrium. Exit, on the other hand, is viewed as a pure market strategy that is both individually improving and helps to discover the true market equilibrium. In the Marxist view, exit is viewed as an individualistic petit-bourgeois strategy that undermines class consciousness, whereas collective action is the main means for obtaining global and permanent improvements. Our Hirschmanian approach is situated somewhere between the two. It shows the accuracy of the market view in regard to pay and of the Marxist view in regard to working conditions. As such, it invites us to associate the study of collective action and of unionization more strongly with the issue of working conditions, a question that is understudied in the traditional bargaining model. Much collective action is in fact, either directly or 
indirectly, concerned with working conditions. Traditional claims for shorter working days and for increased recruiting, as well as disputes concerning redundancy, are also ways of improving working conditions or of resisting their degradation.

\section{Appendix A}

Table A1. Descriptive table on sample size of three datasets

\begin{tabular}{lrr}
\hline & WERS & REPONSE \\
\hline Original employee survey in 2004-5 & 22,451 & 11,766 \\
Original employee surveys in 2011 & 21,981 & 18,536 \\
Original employer survey in 2004-5 & 2,295 & 2,930 \\
Original employer survey in 2011 & 2,680 & $\mathbf{9 8 9}$ \\
Original panel at the workplace-level & 772 & $\mathbf{8 7 2}$ \\
Achieved samples matched with employee survey & 10,268 & 795 \\
Number of employees present in the panel in 2004-5 & 7,324 & 2,441 \\
Number of employees present in the panel in 2011 & - & 2,550 \\
Original DMMO-EMMO (2006) survey & - & 83,465 \\
Achieved samples matched with DMMO-EMMO (2006) & & 597 \\
\hline
\end{tabular}

Source: WERS (2004-11); REPONSE (2005-11); DMMO-EMMO (2006). In bold, the size of the establishment samples used for our main analyses.

Table A2. Voice and exit strategies in SalSa

\begin{tabular}{cccr}
$\begin{array}{c}\text { Yes } \\
\text { (per cent) }\end{array}$ & $\begin{array}{c}\text { No } \\
\text { (per cent) }\end{array}$ & $\begin{array}{c}\text { Doesn't } \\
\text { know } \\
\text { (per cent) }\end{array}$ & N. Obs. \\
\hline 23 & 76 & 1.0 & 3117 \\
& & & \\
23 & 74 & 2.7 & 704 \\
& & & \\
26 & 70 & 4.2 & 704 \\
18 & 81 & 0.5 & 3117 \\
& & & \\
42 & 57 & 1.2 & 570 \\
50 & 82 & 2.3 & 3117 \\
5.7 & 46 & 4.6 & 504 \\
& 94 & & 3117 \\
\hline
\end{tabular}

Note: In bold, the key variables used for the analysis of voice and exit.

Source: SalSa (Insee, ANR, CMH, CREST, 2009). 
Table A3. Descriptive statistics and correlations for Table 4

\begin{tabular}{lcccccccrr}
\hline & Mean & SD & Min & Max & \multicolumn{4}{c}{$\boldsymbol{N}$} & \multicolumn{4}{c}{ Correlation matrix } \\
\hline WERS & & & & & & 1 & 2 & 3 & 4 \\
1. Collective action & 0.17 & 0.38 & 0.00 & 1.00 & 767 & 1.00 & -0.14 & 0.12 & 0.21 \\
2. Exit & 0.08 & 0.11 & 0.00 & 0.86 & 714 & & 1.00 & -0.03 & -0.28 \\
3. Poor working conditions & 1.41 & 0.48 & 0.00 & 4.00 & 772 & & & 1.00 & 0.04 \\
4. Pay & 3.78 & 0.64 & 1.59 & 6.03 & 772 & & & & 1.00 \\
REPONSE & & & & & & 5 & 6 & 7 & 8 \\
5. Collective action & 0.33 & 0.47 & 0.00 & 1.00 & 795 & 1.00 & -0.23 & 0.05 & 0.23 \\
6. Exit & 0.04 & 0.06 & 0.00 & 0.62 & 597 & & 1.00 & 0.08 & -0.22 \\
7. Poor working conditions & 2.29 & 0.74 & 0.97 & 3.86 & 795 & & & 1.00 & -0.16 \\
8. Pay & 5.39 & 0.80 & 2.78 & 9.42 & 795 & & & & 1.00 \\
\hline
\end{tabular}

Note: Descriptive statistics are established at the establishment level. The poor working conditions index and the pay variable (logged) were standardized at the individual level before aggregation at the establishment level. Therefore, once units of observation are establishments, the standard deviations of these variables differ from 1.

Source: WERS (2004-11); REPONSE (2005-11).

Table A4. WERS complete regressions (Table 4, models 1 \& 2)

\begin{tabular}{|c|c|c|c|}
\hline & $\begin{array}{l}\text { Descriptive } \\
\text { statistics }\end{array}$ & Voice (logistic) & $\begin{array}{l}2011 \text { exit } \\
\text { rate (OLS) }\end{array}$ \\
\hline Intercept & Mean (SD) & $-38.28 * * *(10.94)$ & $27.04 * * *(9.74)$ \\
\hline Poor working conditions & $1.41(0.48)$ & $0.87 * * *(0.31)$ & $0.62(0.80)$ \\
\hline Log of hourly pay & $3.78(0.64)$ & $0.01(0.35)$ & $-2.10 * *(0.93)$ \\
\hline $\begin{array}{l}\text { Average working hours per worker } \\
\text { in the establishment }\end{array}$ & $35.5(7.6)$ & $0.25(0.18)$ & $0.15(0.27)$ \\
\hline Average working hours (squared) & 1314.3. (509.5) & $-0.00(0.00)$ & $-0.00(0.00)$ \\
\hline $\begin{array}{l}\text { Average tenure of workers } \\
\text { in the establishment }\end{array}$ & $6.37(2.94)$ & $-0.16(0.24)$ & $-1.79 * * *(0.54)$ \\
\hline Average tenure (squared) & & $0.02(0.02)$ & $0.08 * *(0.04)$ \\
\hline $\begin{array}{l}\text { Average age of workers } \\
\text { in the establishment }\end{array}$ & $40.60(6.55)$ & $1.43 * * *(0.51)$ & $-0.59(0.50)$ \\
\hline Average age (squared) & $1691.7(507.29)$ & $-0.02 * * *(0.01)$ & $0.01(0.01)$ \\
\hline Workplace size & $424.34(926.88)$ & $0.00 * *(0.00)$ & $0.00(0.00)$ \\
\hline $\begin{array}{l}\text { Proportion of females } \\
\text { in the establishment }\end{array}$ & $0.56(0.31)$ & $0.08(0.72)$ & $-0.14(1.83)$ \\
\hline $\begin{array}{l}\text { Occupation (ref = blue-collar): } \\
\text { Proportion of managers }\end{array}$ & $0.22(0.22)$ & $-0.44(0.84)$ & $-3.00(2.63)$ \\
\hline ... of technicians and intermediates & $0.35(0.30)$ & $-0.29(0.66)$ & $-3.19 *(1.90)$ \\
\hline .. of clerks & $0.21(0.30)$ & $-1.80 * *(0.80)$ & $4.55 * *(1.90)$ \\
\hline $\begin{array}{l}\text { Academic diploma }(\mathrm{ref}=\text { no diploma }) \\
\text { Proportion of primary education }\end{array}$ & $0.07(0.12)$ & $-2.22(2.15)$ & $7.06 *(4.02)$ \\
\hline$\ldots$ of GCSE & $0.27(0.19)$ & $0.38(1.17)$ & $4.20(2.90)$ \\
\hline$\ldots$ of 1 A level grade & $0.06(0.08)$ & $-2.22(2.15)$ & $1.61(5.08)$ \\
\hline$\ldots$ of $2 \&$ more $A$ level grades & $0.09(0.11)$ & $-0.74(1.69)$ & $1.98(3.97)$ \\
\hline ... of Undergraduate degree & $0.19(0.19)$ & $0.30(1.30)$ & $7.26 * *(3.32)$ \\
\hline ... of Postgraduate degree & $0.07(0.12)$ & $0.36(1.63)$ & $10.60 * *(4.74)$ \\
\hline$\ldots$ of other & $0.10(0.13)$ & $0.29(1.50)$ & $14.45 * * *(3.65)$ \\
\hline Sector (ref = health): Manufacturing & 0.120 .01 & $-18.47(1080.07)$ & $-0.56(1.70)$ \\
\hline Energy & $0.01(0.10)$ & $-18.26(3712.38)$ & $-1.30(3.72)$ \\
\hline
\end{tabular}


Table A4. Continued

\begin{tabular}{lccr}
\hline & $\begin{array}{c}\text { Descriptive } \\
\text { statistics }\end{array}$ & Voice (logistic) & \multicolumn{1}{c}{$\begin{array}{c}\text { 2011 exit } \\
\text { rate (OLS) }\end{array}$} \\
\hline Construction & $0.04(0.20)$ & $-0.29(0.73)$ & $0.77(2.17)$ \\
Whole sale and retail & $0.10(0.30)$ & $-16.70(1016.77)$ & $-0.05(1.48)$ \\
Hotel & $0.04(0.20)$ & $-0.48(1.17)$ & $7.90^{* * *}(2.20)$ \\
Transport & $0.07(0.26)$ & $-2.15^{* *}(0.95)$ & $-4.23^{* *}(1.98)$ \\
Finance, insurance, & $0.12(0.33)$ & $-0.71(0.59)$ & $2.25(1.45)$ \\
$\quad$ and service to business & $0.30(0.29)$ & $1.86^{* * *}(0.42)$ & $-0.96(1.60)$ \\
Administration & $0.13(0.33)$ & $1.70^{* * *}(0.41)$ & $-2.02(1.47)$ \\
Education & $/$ & 0.41 & 0.25 \\
Pseudo R2/R2 & 759 & 759 & 706 \\
Number of observations & & & \\
$\quad$ (i.e. establishments) & & & \\
\hline
\end{tabular}

Notes: All independent variables are measured in 2004, prior to the voice and exit events. Poor working conditions index and log hourly pay are standardized with their standard deviation at the individual level. The coefficients in the exit models are presented in percentage points.

Control variables are not standardized. In the exit OLS regression model, the dependent variable (establishment average exit rate) is in percentages. The coefficients are expressed in percentage points. Standard errors are in parentheses.

*Statistically significant at the 0.10 level; **at the 0.05 level; ***at the 0.01 level.

Table A5. REPONSE complete regressions (Table 4, models 3 \& 4)

\begin{tabular}{|c|c|c|c|}
\hline & $\begin{array}{l}\text { Descriptive } \\
\text { statistics }\end{array}$ & $\begin{array}{c}\text { Voice } \\
\text { (Logistic) }\end{array}$ & $\begin{array}{l}2006 \text { exit } \\
\text { rate (OLS) }\end{array}$ \\
\hline Intercept & Mean (SD) & $-7.67^{* * *}(3.00)$ & $21.22^{* * *}(5.92)$ \\
\hline Poor working conditions & $2.29(0.74)$ & $0.28^{* *}(0.13)$ & $0.42(0.30)$ \\
\hline Log of hourly pay & $5.39(0.80)$ & $0.67^{* * *}(0.19)$ & $-1.39^{* * *}(0.45)$ \\
\hline $\begin{array}{l}\text { Average working hours per worker } \\
\text { in the establishment }\end{array}$ & $32.5(7.6)$ & $0.04(0.05)$ & $-0.20^{*}(0.10)$ \\
\hline Average working hours (squared) & $1111(475.5)$ & $-0.00(0.00)$ & $0.00^{* *}(0.00)$ \\
\hline $\begin{array}{l}\text { Average tenure of workers } \\
\text { in the establishment }\end{array}$ & $13.6(7.6)$ & $0.09(0.05)$ & $-0.15(0.12)$ \\
\hline Average tenure (squared) & 241.9 (260.9) & $-0.00(0.00)$ & $0.00(0.00)$ \\
\hline Average age of workers in the establishment & $39.97(7.37))$ & $0.10(0.14)$ & $-0.39(0.29)$ \\
\hline Average age (squared) & $1652(589.11)$ & $-0.00(0.00)$ & $0.01(0.00)$ \\
\hline Workplace size & $323(452.4)$ & $0.00^{* * *}(0.00)$ & $-0.00(0.00)$ \\
\hline blishment & $0.43(0.39)$ & $-0.34(0.30)$ & $-0.29(0.67)$ \\
\hline $\begin{array}{l}\text { Occupation (ref }=\text { non-qualified blue } \\
\text { collar): Proportion of managers }\end{array}$ & $0.18(0.29)$ & $-1.76^{* * *}(0.66)$ & $0.23(1.43)$ \\
\hline$\ldots$ of intermediates & $\begin{array}{r}0.28 \\
(0.33)\end{array}$ & $\begin{array}{l}-0.34 \\
(0.48)\end{array}$ & $\begin{array}{r}0.68 \\
(1.11)\end{array}$ \\
\hline$\ldots$ of clerks & $0.20(0.33)$ & $-1.00^{* *}(0.50)$ & $1.26(1.12)$ \\
\hline$\ldots$ of qualifie & $0.22(0.33)$ & $-0.46(0.46)$ & $-0.04(1.08)$ \\
\hline Diploma $(\mathrm{ref}=$ no diploma): Proportion of BEPC & $0.07(0.18)$ & $0.38(0.60)$ & $0.42(1.35)$ \\
\hline ... CAP & $0.06(0.16)$ & $-0.61(0.68)$ & $-2.89^{* *}(1.42)$ \\
\hline Baccalauréat & $0.33(0.34)$ & $-0.02(0.40)$ & $-0.98(0.92)$ \\
\hline$\ldots \mathrm{BAC}+2$ & $0.13(0.24)$ & $0.38(0.50)$ & $0.27(1.13)$ \\
\hline$\ldots \mathrm{BAC}+3$ or +4 & $0.16(0.25)$ & $0.06(0.48)$ & $-0.34(1.10)$ \\
\hline
\end{tabular}


Table A5. Continued

\begin{tabular}{lcrr}
\hline & $\begin{array}{c}\text { Descriptive } \\
\text { statistics }\end{array}$ & \multicolumn{1}{c}{$\begin{array}{c}\text { Voice } \\
\text { (Logistic) }\end{array}$} & \multicolumn{1}{c}{$\begin{array}{c}\text { 2006 exit } \\
\text { rate (OLS) }\end{array}$} \\
\hline . BAC + 4 and more & $0.07(0.17)$ & $0.07(0.62)$ & $0.48(1.36)$ \\
Sector (ref = health):Manufacturing & $0.38(0.49)$ & $-0.32(0.34)$ & $-1.20(0.86)$ \\
$\quad$ Energy & $0.01(0.11)$ & $1.29(0.94)$ & $-1.57(2.04)$ \\
Construction & $0.06(0.24)$ & $-1.59^{* *}(0.62)$ & $3.03^{* *}(1.23)$ \\
Wholesale and retail & $0.14(0.35)$ & $-1.11^{* * *}(0.41)$ & $2.11^{* * *}(0.91)$ \\
Hotel and restaurants & $0.03(0.16)$ & $-0.77(0.71)$ & $14.11^{* * * *}(1.64)$ \\
Transport and communication & $0.08(0.27)$ & $0.20(0.43)$ & $0.23(1.10)$ \\
Finance, insurance, and service to business & $0.11(0.31)$ & $-0.78^{*}(0.41)$ & $1.66^{*}(0.95)$ \\
Real estate & $0.01(0.12)$ & $-1.55^{*}(0.86)$ & $-1.61(1.88)$ \\
Education & $0.03(0.16)$ & $0.57(0.57)$ & $2.69^{*}(1.41)$ \\
Other community services & $0.02(0.16)$ & $-2.32^{* *}(1.15)$ & $2.77^{*}(1.44)$ \\
Number of observations $(i . e$. establishments) & 795 & 795 & 590 \\
Pseudo R2/R2 & $/$ & 0.22 & 0.32 \\
\hline
\end{tabular}

Notes: All independent variables are measured in 2005, prior to the voice and exit events. In the regressions, poor working conditions and hourly pay are standardized with their standard deviation at the individual level. The coefficients in the exit models are presented in percentage points. Control variables are not standardized. In the exit OLS regression model, the dependent variable (establishment average exit rate) is percentages. Standard deviations (descriptives) and standard errors (regressions) are in parentheses.

*Statistically significant at the 0.10 level; **at the 0.05 level; ***at the 0.01 level.

Table A6. Variation in voice or exit variables in the SalSa survey

\begin{tabular}{lcccc}
\hline & & \multicolumn{2}{c}{ Independent variables in $\boldsymbol{t}-\mathbf{1}$} \\
\cline { 3 - 4 }$\downarrow$ Dependent variables in $\boldsymbol{t}$ & $\begin{array}{c}\text { Mean prop. } \\
\text { (per cent) }\end{array}$ & $\begin{array}{c}\text { Poor working } \\
\text { conditions }\end{array}$ & $\begin{array}{c}\text { Log of } \\
\text { hourly pay }\end{array}$ & N. Obs. \\
\hline 1. Collective action in 2004-8 & 23 & $1.45^{* * *}$ & $1.22^{* * *}$ & 2466 \\
2. Exit in 2004-8 & 18 & 1.04 & $0.83^{* *}$ & 2476 \\
3. Collective action successful & 10 & $1.27^{* * *}$ & 1.04 & 2474 \\
4. Collective action pay increasing & 5 & $1.19^{*}$ & 1.06 & 2466 \\
5. Collective action gives other advantage & 6 & $1.38^{* * *}$ & 1.20 & 2466 \\
6. Exit for pay & 8 & 1.05 & $0.73^{* *}$ & 2476 \\
7. Exit for other reason & 10 & 1.02 & 0.98 & 2476 \\
8. Intends to quit & 16 & $1.52^{* * *}$ & $0.82^{* *}$ & 2899 \\
9. Intends to quit for pay & 8 & $1.48^{* * *}$ & $0.73^{* * *}$ & 2899 \\
10. Intends to quit for other reason & 7 & $1.4^{* * *}$ & 0.93 & 2899 \\
11. Exit in 2009 (after the survey) & 6 & 1.08 & 0.77 & 1959 \\
\hline
\end{tabular}

Notes: Each line corresponds to a different logistic regression. Parameters are $\times$ standardized. We display here parameters' odds ratios. Control variables in all models include working hours (simple and squared), age (simple and squared), size of the establishment, gender, occupation, diploma and industry.

We use 2009 dependant variables, 2008 working conditions, $2003 \log$ hourly pay for models 1-7, and $2008 \log$ hourly pay for models $8-11$.

*Statistically significant at the 0.10 level; **at the 0.05 level; ***at the 0.01 level. 
Table A7. The impact of poor working conditions and pay on collective voice and exit in when controlling for the competitive environment

\begin{tabular}{|c|c|c|c|c|}
\hline & \multicolumn{2}{|c|}{ WERS } & \multicolumn{2}{|c|}{ REPONSE } \\
\hline & Voice & Exit & Voice & Exit \\
\hline $\begin{array}{l}\text { Poor working } \\
\text { conditions }\end{array}$ & $0.75^{* *}(0.32)$ & $1.01(0.80)$ & $0.28 * *(0.13)$ & $0.43(0.31)$ \\
\hline Pay & $-0.23(0.36)$ & $-1.84 * *(0.92)$ & $0.67 * * *(0.19)$ & $-1.38 * * *(0.45)$ \\
\hline $\begin{array}{l}\text { High degree of } \\
\text { competition } \\
\text { (WERS) or Firm's } \\
\text { share of the } \\
\text { market below } \\
25 \text { per cent } \\
\text { (REPONSE) }\end{array}$ & $-0.48 * * *(0.13)$ & $1.16^{* * *}(0.30)$ & $-0.39(0.19)$ & $0.10(0.44)$ \\
\hline Pseudo R2 or R2 & 0.43 & 0.27 & 0.23 & 0.32 \\
\hline Model & Logit & OLS & Logit & OLS \\
\hline $\begin{array}{l}\text { Number of } \\
\text { observations (i.e. } \\
\text { establishments) }\end{array}$ & 759 & 706 & 795 & 590 \\
\hline
\end{tabular}

Note: Control variables in all models include size and industry of the establishment, and establishment averages of working hours (simple and squared), age (simple and squared), tenure (simple and squared), and of gender, occupation, and diploma dummies.

In order to control for the competitive environment, we considered the workplaces whose degree of competition is high in the market in the WERS survey and the firms whose share of the market is 50 per cent and over in the REPONSE survey.

*Statistically significant at the 0.10 level; **at the 0.05 level; ***at the 0.01 level.

\section{Appendix B}

\section{Description of the SalSa survey}

This is a cross-sectional survey of 3000 French employees undertaken in December 2008 and January 2009, with a special interest in the way they perceive their wages (SalSa, Les Salaires vus par les Salariés). In order to constitute the SalSa sample, Insee extracted a random sample of employees from the 2006 Panel DADS (Déclaration Annuelle des Données Sociales). In order to overcome the under-representation of the public sector in DADS, the designers of the survey decided to oversample employees of public hospitals and local governmental administrations. As such, 20 per cent of the initial sample was selected from these two groups. Similarly, 10 per cent of the sample was selected from the top decile of the private sector's wage distribution. The final sample is constituted of 3117 interviews. We were therefore able to match responses to the cross-sectional survey with a limited selection of variables (due to privacy issues) from the Panel DADS. This selection mainly contains the employees' work career (wages, number of working hours, industry, occupation, type of job) since 1976. Table A2 presents the descriptive table of the exit and voice variables in the SalSa survey. 
Poor working conditions in SalSa

In the SalSa survey, we built the index of poor working conditions with the negative items of the six working conditions variables. The latter are high-speed work (all the time: 43 per cent), physically hard work (yes: 37 per cent), mentally hard work (yes: 64 per cent), dangerous work (yes: 27 per cent), convenient working schedule (no: 17 per cent), and the fact of liking the work (sometimes and never: 10 per cent).

Unfortunately, the survey provides information on working conditions only at the end of 2008. We therefore use here the 2008 poor working conditions index as a proxy for the 2003 one. Nevertheless, we will remain cautious in our interpretation of this last model as these estimations could suffer from a temporal bias because we use present working conditions to explain a past voice event.

\section{Pay in SalSa}

The great advantage of SalSa is that it provides detailed information about employees' full careers. Here, we take into account the net salary of individuals (firm declared) and the number of working hours (firm declared, as well) in order to compute the log hourly wage. This variable is calculated both for 2003 and 2008.

\section{Control variables in SalSa}

In the SalSa survey, the models control for individual characteristics (gender, age, education, working hours, occupation) as well as for industry and establishment size. Most variables are defined in 2003 before the eventual collective action or exit events took place. Only education comes from the 2008 survey. But, most generally, it refers to the education level prior to the start of the career.

\section{Notes}

\footnotetext{
${ }^{1}$ In his book, Hirschman (1970) insists mostly on the informational content of voice which enables quality improvements. He also pinpoints 'the cost of obtaining information about substitute products to which one intends to switch' (p. 40). In a follow-up paper, Hirschman pushes even further the causal role of quality uncertainty in the exit-voice arbitrage: 'To repeat, the second new criterion for discriminating between exit-prone and voice-prone situations can be defined as ignorance and uncertainty, shared by consumers and producers, about the manner of procuring a desired good or service and, in fact, about their precise nature. (...) In such situations, then, the use of voice rather than exit is to be expected and recommended (...)' (1974, p. 438).

${ }^{2}$ OECD: https://stats.oecd.org.

${ }^{3}$ In appendix, we also provide a supplementary confirmation of our findings for France thanks to the SalSa (2009) survey.

${ }^{4}$ There are some establishments where managers were interviewed but the employees' answers are missing. These establishments were therefore excluded from the panel reducing the final sample size for the WERS survey to 772 and for the REPONSE survey to 795.

${ }^{5}$ This figure is comparable with what we find from other sources. According to Eurostat, in 2011 the turnover rate in UK was 7.8 .

${ }^{6}$ For instance a respondent agreeing with the fact that his job requires hard work but reporting good working conditions to the six other questions will have an unstandardized poor working condition score of 1 .
} 
${ }^{7}$ In WERS 2004, the weekly pay is banded in fourteen intervals. In order to turn this categorical variable into a numeric one, we use the middle of the intervals for the intermediary categories. We use a log-normal estimation of the average wage for workers in the first and the last intervals.

${ }^{8}$ We checked that both weighting the regressions and adjusting the weights for non-response (i.e. workplaces which did not return employee questionnaires) yielded similar results. These supplementary results will be sent on request.

${ }^{9}$ We also checked that the results still hold when we remain at the same level of measure and use for that aim the 2011 individual working conditions instead of 2005 establishment working conditions. Moreover, this enables to introduce an establishment fixed effect and show that the effect of individual correlation between poor working conditions on voice is not driven by between establishments unobserved heterogeneity. However, in those two estimations, individual working conditions are postdetermined and estimates may suffer from a temporal bias. It is possible to correct this bias by instrumenting the 2011 working individual working conditions with the 2005 establishment ones. The results still hold under the assumption of the exclusion hypothesis. None of these three strategies is perfect. However, they all yield similar results and provide robustness to our estimates. Results will be sent on request.

${ }^{10}$ Estimations will be sent on requests.

${ }^{11}$ Pay is logged and standardized at the individual level.

${ }^{12}$ One standard deviation of pay corresponds to 0.56 logarithm of hourly wage in WERS, 0.44 in REPONSE.

${ }^{13}$ We would like to thank an anonymous referee for suggesting this strategy.

\section{References}

Acemoglu D. (2001) 'Good Jobs Versus Bad Jobs', Journal of Labor Economics 19(1): 1-21.

Amossé T. and Forth J. (2016) 'Employee Expression and Representation at Work: Voice or Exit?' in Amossé T., Bryson A., Forth J. and Petit H. (eds.) Comparative Workplace Employment Relations, London: Palgrave Macmillan: 61-103.

Andolfatto D. and Labbé D. (2009) Toujours moins! Déclin du syndicalisme à la française. Paris: Gallimard.

Askenazy P. (2004) Les désordres du travail: Enquête sur le nouveau productivisme. Paris: Seuil.

Barry B. (1974) 'Review Article: Exit, Voice and Loyalty', British Journal of Political Science 4(1): 79-107.

Böckerman P. and Ilmakunnas P. (2006) 'Do Job Disamenities Rase Wages or Ruin Job Satisfaction?', International Journal of Manpower 27(3): 290-302.

Bockerman P., Bryson A. and Ilmakunnas P. (2012) 'Does High Involvement Management Improve Worker Wellbeing?', Journal of Economic Behavior and Organization 84(6): 660-680.

Boroff K. E. and Lewin D. (1997) 'Loyalty, Voice and Intent to Exit a Union Firm: A Conceptual and Empirical Analysis', Industrial and Labor Relations Review 51(1): 50-63.

Brown A., Charlwood A. and Spencer D. A. (2012) 'Not All that it Might Seem: Why Job Satisfaction is Worth Studying Despite it Being a Poor Summary Measure of Job Quality', Work, Employment, and Society 26(6): 1007-1018.

Bryson A. (2004) 'Managerial Responsiveness to Union and Nonunion Worker Voice in Britain', Industrial Relations 43(1): 213-241.

Bryson A. and Forth J. (2009) Union Organisation and the Quality of Employment Relations. London: Trades Union Congress.

Bryson A., Willman P., Gomex R. and Kretschmer T. (2013) 'The Comparative Advantage of Nonunion Voice in Britain', Industrial Relations, 52(suppl.): 194-200.

Bryson A., Forth J. and Stokes L. (2017) 'Does Worker Wellbeing Affect Workplace Performance?', Human Relations 70(8): 1017-1037. https://doi.org/10.1177/001872671769307. 
Budd J.W. (2005) 'The effects of unions on employee benefits and non-wage compensation: monopoly power, collective voice, and facilitation', Unpublished manuscript, Industrial Relations Center, University of Minnesota.

Clark A. (2001) 'What Really Matters in a Job? Hedonic Measurement Using Quit Data', Labour Economics 8(2): 223-242.

Clark A. (2011) 'Worker Well-being in Booms and Busts' in Gregg P. and Wadswoth J. (eds.) The Labour Market in Winter: The State of Working Britain, Oxford: Oxford University Press: $128-143$.

Cooke G. B., Donaghey J. and Zeytinoglu I. U. (2013) 'The Nuanced Nature of Work Quality: Evidence from Rural Newfoundland and Ireland', Human Relations 66(4): 503-527.

Cottini E., Kato T. and Westergaard-Nielsen N. (2011) 'Adverse Workplace Conditions, High Involvement Work Practices and Labour Turnover: Evidence from Danish Linked Employeremployee Data', Labour Economics 18(6): 872-880.

Coutrot T. (1998) 'Relations La force de la loi et le royaume du contrat', Travail et Emploi 75: 97115.

Davoine L., Erhel C. and Guergoat-Larivière M. (2008) 'Monitoring Employment Quality in Work: European Employment Strategy Indicators and Beyond', International Labour Review 147(23): 163-198.

De Bustillo R. M., Fernández-Macías E., Esteve F. and Anton J.-I. (2011) 'E pluribus unum? A critical survey of job quality indicators', Socio-Economic Review 9(3): 447-475.

Dickens W. T. and Katz F. (1987) 'Inter-industry Wage Differences and Theories of Wage Determination' in Lang K. and Leonard J. (eds.) Unemployment and the Structure of Labor Markets, New York: Basil Blackwell: 48-89.

Dowding K. J. P., Mergoupis T. and Van Vugt M. (2000) 'Exit, Voice and Loyalty: Analytic and Empirical Developments', European Journal of Political Research 37(4): 469-495.

Freeman R. B. (1976) 'Individual Mobility and Union Voice in the Labor Market', American Economic Review 66(2): 361-368.

Freeman R. B. (1978) 'Job Satisfaction as an Economic Variable', American Economic Review 68(2): 135-141.

Freeman R. B. (1980) 'The Exit-voice Tradeoff in the Labor Market: Unionism, Job Tenure, Quits, and Separations', Quarterly Journal of Economics 94(4): 643-673.

Freeman R. B. and Medoff J. L. (1984) What do Unions do?. New York: Basic Books.

Garcia-Serrano C. (2004) 'Temporary Employment, Working Conditions and Expected Exits from Firms', LABOUR 18(2): 293-316.

Godechot O. and Gurgand M. (2000) 'Quand les salariés jugent leur salaire', Économie et statistique 331(1): 3-24.

Gollac M. (1997) 'Des chiffres insensés? Pourquoi et comment on donne un sens aux données statistiques', Revue française de sociologie 38(1): 5-36.

Green F., Mostafa A., Parent-Thirion A., Vermeylen G., Van Houten G., Biletta I. and Lyly-Yrjanainen M. (2013) Is Job Quality Becoming More Unequal?, Industrial and Labour Relations Review 66(2): 753-794.

Hammer T. H. (2000) 'Nonunion Representational Forms: An Organizational Behavior Perspective', in Kaufman T. and Mitchell D. G. (eds.) Non-Union Employee Reoresentation; History, Contemporary Practice and Policy, Armonk, NY: ME Sharpe, 176-195.

Hirschman A. O. (1970) Exit, Voice and Loyalty: Responses to Decline in Firms, Organizations, and States. Cambridge, Massachusetts: Harvard University Press.

Hirschman A. O. (1974) 'Exit, Voice and Loyalty: Further Reflections and a Survey of Recent Contributions', Social Science Information 13(1): 7-26.

Kristensen N. and Westergard-Nielsen N. (2006) 'Job Satisfaction and Quits-Which Job Characteristics Matters Most?', Danish Economic Journal 144(2): 230-248.

Levy-Garboua L., Montmarquette C. and Simonnet V. (2007) 'Job Satisfaction and Quits', Labour Economics 14(2): 251-268. 
MacLeod W. B. and Malcomson J. (1993) 'Investments, Holdup, and the Form of Market Contracts', American Economic Review 83(4): 811-837.

McPherson M., Smith-Lovin L. and Cook J. M. (2001) 'Birds of a Feather: Homophily in Social Networks', Annual Review of Sociology 27(1): 415-444.

Miller P. and Mulvey C. (1991) 'Australian Evidence on the Exit/Voice Model of the Labor Market', Industrial and Labor Relations Review 45: 44-47.

Osterman P. (2013) 'Introduction to the Special Issue on Job Quality: What does It Mean and How We Might Think About It?', Industrial and Labor Relations Review, Special Issue 66(4): 739752.

Rosen S. (1986) 'The Theory of Equalizing Differences' in Ashenfelter O. and Layard R. (eds.) Handbook of Labor Economics, Vol. 1. London: Elsevier: pp. 641-692.

Sehnbruch K. (2004) From Quantity to the Quality of Employment: An Application of the Capability Approach to the Chilean Labor Market?, Working Paper Series no. 9: Centre for Latin American Studies, University of California, Berkeley.

Sen A. (1999) Development as Freedom. Oxford: Oxford University Press.

Sen Gupta S., Edwards P. K. and Tsai C. J. (2009) 'The Good, the Bad, and the Ordinary: Work Identities in "Good" and "Bad" Jobs in the United Kingdom', Work and Occupations 36(1): $26-55$.

Shields M. A. and Price S. W. (2002) 'Racial Harassment, Job Satisfaction and Intentions to Quit: Evidence from the British Nursing Profession', Economica 69(274): 295-326.

Stride C., Wall T. D. and Catley N. (2007) Measures of Job Satisfaction, Organisational Commitment, Mental Health, and Job-related Well-being: A Benchmarking Manual, 2nd edn. Chichester: Wiley.

Van Ophem H. (1991) 'Wages, Nonwage Job Characteristics and the Search Behavior of Employees', Review of Economics and Statistics 73: 145-151.

Van Wanrooy B. et al. (2013) Employment Relations in the Shadow of Recession: Findings from the 2011 Workplace Employment Relations Study. Croydon: Palgrave Macmillan.

Willman P., Gomez R. and Bryson A. (2009) 'Voice at the Workplace: Where do We Find It, Why is it there and Where is it Going?' in Brown W., Bryson A., Forth J. and Whitfield K. (eds.) The Evolution of the Modern Workplace. Cambridge: Cambridge University Press: 97-119.

Wood S. (2008) 'Job Characteristics, Employee Voice and Well-being in Britain', Industrial Relations Journal 39(2): 153-168. 